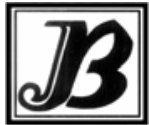

J. bio-sci. 19: 23-27, 2011

ISSN 1023-8654

http://www.banglajol.info/index.php/JBS/index

\title{
ANTIDIABETIC ACTIVITY OF CENTELLA ASIATICA (L.) URBANA IN ALLOXAN INDUCED TYPE 1 DIABETIC MODEL RATS
}

\author{
Sonia Rahman, M A H Mostofa Jamal, Anzana Parvin, Md Mahfuz-Al-Mamun, M Rezuanul Islam* \\ Department of Biotechnology and Genetic Engineering, Islamic University, Kushtia-7003, Bangladesh
}

\begin{abstract}
Context: Diabetes mellitus is becoming a major burden upon healthcare facilities in all affected countries. Current therapies used for diabetics have side effects, so the current shift to the use of herbal preparations may be more effective, relatively low cost, less side effect and low toxicity.

Objective: The present research was made to investigate the potential antidiabetic activity of Centella asiatica (L.) Urb. in alloxen induced diabetics.

Materials and Methods: Rats were divided into 6 groups and C. asiatica was administered containing 50, 100 and $200 \mathrm{mg} / \mathrm{kgbwt}$ powder, respectively in $1 \mathrm{ml}$ water orally in group $\mathrm{A}, \mathrm{B}$ and $\mathrm{C}$ rats. Metformin (150 mg/kgbwt) used as a reference standard drug. Blood glucose (BG), triglycerides (TG), total cholesterol (TC), high density lipoproteins $(\mathrm{HDL})$, low density lipoproteins (LDL), serum glutamate oxaloacetate transaminase (SGOT) and serum glutamate pyruvate transaminase (SGPT) were estimated from the serum by using standard kits.

Results: C. asiatica juice had shown significant lowered the blood glucose levels in all groups. In addition, body weight, organ (liver, kidney, heart and pancreas) weight, food intake, water intake were also examined in all treated groups and compared against diabetic control group. After 22 days daily administration of $C$. asiatica, diabetic treated rats showed improvement in body weight, water intake as compared to diabetic control rats. In alloxan induced diabetic rats the maximum reduction in BG, TG, TC, HDL, LDL, SGOT and SGPT were observed at a dose level of $50 \mathrm{mg} / \mathrm{kgbwt}$.

Conclusion: The present data indicates that $\mathrm{C}$. asiatica juice possesses potential as an antidiabetic action
\end{abstract}

Keywords: Diabetes mellitus, Antidiabetic, Centella asiatica, Blood glucose, Triglycerides, Cholesterol.

\section{Introduction}

Diabetes mellitus is a continuously growing health problem, which causes substantial morbidity, mortality and long-term complications even in developed countries. The prevalence of diabetes for all age-groups worldwide was estimated to be $2.8 \%$ in 2000 and $4.4 \%$ in 2030 (Haffner et al. 1998). In the past decade, the United States has recorded a 33\% rise in the cases diabetes. About 150 million or 1.3\% people are suffering from diabetes world wide which is almost five times more than the estimates ten years ago and this may double by the year 2030 (Ghosh et al. 2004)

Plants have been the major source of drug for the treatment of diabetes mellitus in Indian system of medicine and other ancient systems in the world. The importance of antidiabetic plants in the development of economic and effective treatment for diabetes, currently estimated to affect over 30 million people worldwide (WHO 1985). Plant drugs (Bailey and Day 1989) and herbal formulation (Mitra et al. 1996, Annapurna $C$. 2001, Battacharya et al. 1997) are frequently considered to be less toxic and more free from side effects than synthetic one. Based on the WHO recommendations (WHO 1980) hypoglycemic agents of plant origin used in traditional medicine are important.

Centella asiatica (L.) Urbana or locally known as thankuni, is a weakly aromatic smelling herb of the family Umbelliferare. It has been used widely in folk medicine for hundreds of years to treat a wide range of illness (Brinkhaus et al. 2000). It is used in traditional and alternative medicine due to the wide spectrum of

"Corresponding author Email: rezwangbt@yahoo.com 
pharmacological activities associated with these secondary metabolites (James and Dubery 2009). It accumulates large quantities of pentacyclic triterpenoid saponins, collectively known as centelloids.

In this present study, the effects of $C$. asiatica juice on blood glucose levels were evaluated in hyperglycemic and assessed by evaluating the comparative hypolipidemic (total cholesterol (TC), low density lipoproteins (LDL), high density lipoproteins (HDL) and triglyceride (TG)) and hepatoprotective (serum glutamate oxaloacetate transaminase (SGOT) and serum glutamate pyruvate transaminase (SGPT)) activities in alloxan-induced diabetic rats and compared with those of metformin.

\section{Materials and Methods}

Plant extract and test animal: Fresh C. asiatica plants were collected from medicinal plant garden. The plant parts were shade dried completely in room and the dried plants were powdered with an electric grinder into fine powder and used for making juice. The authenticity of the Centilla asiatica was identified by the department of Botany, Rajshahi University, Rajshahi.

A total number of 23 male long evan rat (140-250 g) were used in the experiment. Rats were obtained from the International Centre for Diarrhoeal Diseases Research, Bangladesh. Animals were maintained under standard and ambient temperature under lights for twelve hours followed by $12 \mathrm{~h}$ of darkness environmental conditions having proper ventilation in the room, were fed with a standard pellet diet and water.

Induction of diabetes and experimental procedure: Male long evan rats were divided into 6 groups and allowed to fast overnight and injected single intraperitoneal injection with freshly prepared alloxan monohydrate (120 mg/kgbwt) in saline water to made diabetic by alloxan monohydrate and served as diabetic control, standard and treatment groups respectively. Rats exhibited in plasma glucose levels $>10 \mathrm{mmol} / \mathrm{dl}$, 5 day after administration of alloxan were included in the study and selected for drug treatments. Treatment for diabetes (C. asiatica extract 50,100 and $200 \mathrm{mg} / \mathrm{kgbwt}$ ) was started from 6 th day of alloxan administration. Group A, B and C served as sample group were fed a sample (C. asiatica) containing $50 \mathrm{mg} / \mathrm{kgbwt}, 100 \mathrm{mg} / \mathrm{kgbwt}$ and $200 \mathrm{mg} / \mathrm{kgbwt}$ powder respectively in $1 \mathrm{ml}$ water orally (once daily), starting from the $6^{\text {th }}$ day of alloxan administration, one diabetic control group (positive control group) which did not receive metformin or sample, one normal group (negative control group) which received only distilled water, and standard drug group (SD group) which received metformin as standerd drug in $1 \mathrm{ml}$ water orally. The whole experiment was continued for 22 days.

Sample collection and estimation of biochemical parameter: Rats were sacrificed by ether anesthesia and about 3-5 $\mathrm{ml}$ of blood sample was collected directly from artery by syringes. Blood was collected in fresh centrifuge tube and centrifuged at $4000 \mathrm{rpm}$ for $10 \mathrm{~min}$ and the serum was preserved to examine TG, TC, SGPT, SGOT, HDL and LDL level by semi-auto analyzer (Humalyzer 3000, Human, Germany) using wet reagent diagnostic kits according to manufacturer's protocol.

Statistical analysis: Data from the experiments were analyzed using SPSS software for windows version 10. All results were expressed as the mean \pm Standard Deviation. One-way analysis of variance (ANOVA) used and paired or unpaired t-test was done to see any difference between groups.

\section{Results}

Effect of $C$. asiatica on body weight (bwt) gain, food intake and water intake: In the course of investigation it was observed that, there is slightly increasing tendency of body weight in $C$. asiatica juice and Standard drug (SD) administered group at final day (22 ${ }^{\text {th }}$ day) as compared with initial day. Very significant weight loss, approaching $20 \%$, occurred $48 \mathrm{~h}$ after administration of alloxan (120 mg/kgbwt). The final body weight of diabetic control group was found lower than that of normal group (Table 1). Among the treatment, group A gain highest body weight (117\%).Where as group B and $\mathrm{C}$ gain $94 \%$ and $101 \%$, respectively. However, there 
was no significant difference between $C$. asiatica and SD treatment group. It was observed that body weight was found to significantly related with food intake in all groups of rats. Among the three treatment groups the final (22 $2^{\text {nd }}$ day) body weight of group A increase $117 \%$ as food intake of this group was better when compared to diabetic control group. Moreover, improvement of body weight of treated animal further supports the antidiabetogenic effect of $C$. asiatica as diabetic condition is associated with loss of body weight.

Table 1. Effect of Centella asiatica on body weight (bwt) and growth parameter of alloxan induced type 1 diabetic rats for 22 days

\begin{tabular}{|c|c|c|c|c|c|c|c|c|}
\hline $\begin{array}{l}\text { Experimental } \\
\text { Groups }\end{array}$ & $\begin{array}{c}\text { bwt } \\
\text { initial day } \\
\text { (g) }\end{array}$ & $\begin{array}{l}\text { bwt-8th } \\
\text { day (g) }\end{array}$ & $\begin{array}{l}\text { bwt-15 th } \\
\text { day (g) }\end{array}$ & $\begin{array}{l}\text { bwt-22nd } \\
\text { day }(g)\end{array}$ & $\begin{array}{l}\text { Body Weight } \\
\text { (g) }\end{array}$ & $\begin{array}{l}\text { Food Intake } \\
\text { (g/kgbwt) }\end{array}$ & $\begin{array}{l}\text { Water Intake } \\
\text { (ml/kgbwt) }\end{array}$ & $\begin{array}{l}\text { Body Weight } \\
\text { (g) }\end{array}$ \\
\hline Normal & $\begin{array}{c}167.00 \pm \\
13.78 \\
(100 \%)\end{array}$ & $\begin{array}{c}191.75 \pm \\
38.96 \\
(114 \%)\end{array}$ & $\begin{array}{c}194.75 \pm \\
38.39 \\
(116 \%)\end{array}$ & $\begin{array}{c}198.50 \pm \\
43.37 \\
(118 \%) \\
\end{array}$ & $188.00 \pm 14.26^{a}$ & $59.92 \pm 1.06^{a}$ & $186.13 \pm 22.67^{a}$ & $188.00 \pm 14.26$ \\
\hline $\begin{array}{l}\text { Diabetic } \\
\text { control }\end{array}$ & $\begin{array}{c}166.50 \pm \\
22.18 \\
(100 \%)\end{array}$ & $\begin{array}{c}158.25 \pm \\
20.25 \\
(95 \%)\end{array}$ & $\begin{array}{c}149.75 \pm \\
14.17 \\
(90 \%)\end{array}$ & $\begin{array}{c}105.75 \pm 3.86 \\
(64 \%)\end{array}$ & $145.06 \pm 27.08^{b}$ & $44.66 \pm 1.06^{b}$ & $242.00 \pm 17.17^{b}$ & $145.06 \pm 27.08^{b}$ \\
\hline $\begin{array}{l}\text { Diabetic+ } \\
\text { Group A }\end{array}$ & $\begin{array}{c}144.50 \pm \\
40.17 \\
(100 \%)\end{array}$ & $\begin{array}{c}163.25 \pm \\
32.01 \\
(113 \%)\end{array}$ & $\begin{array}{c}164.50 \pm \\
36.70 \\
(114 \%)\end{array}$ & $\begin{array}{c}169.00 \pm \\
32.45 \\
(117 \%)\end{array}$ & $160.31 \pm 10.82^{b}$ & 59.63 & 188.00 & $160.31 \pm 10.82^{b}$ \\
\hline $\begin{array}{l}\text { Diabetic+ } \\
\text { Group B }\end{array}$ & $\begin{array}{c}192.00 \pm 5.44 \\
(100 \%)\end{array}$ & $\begin{array}{c}52.5 \pm 26.66 \\
(80 \%)\end{array}$ & $\begin{array}{c}168.25 \pm \\
27.02 \\
(87 \%)\end{array}$ & $\begin{array}{c}180.5 \pm 38.71 \\
(94 \%)\end{array}$ & $173.31 \pm 16.92^{\mathrm{NS}}$ & $59.25 \pm 2.04 a$ & $198.59 \pm 17$ & $173.31 \pm 16.92^{\mathrm{NS}}$ \\
\hline $\begin{array}{l}\text { Diabetic+ } \\
\text { Group C }\end{array}$ & $\begin{array}{c}154.75 \pm \\
46.34 \\
(100 \%) \\
\end{array}$ & $\begin{array}{c}156.50 \pm \\
35.96 \\
(102 \%) \\
\end{array}$ & $\begin{array}{c}166.25 \pm \\
37.25 \\
(108 \%)\end{array}$ & $\begin{array}{c}166.75 \pm \\
45.50 \\
(108 \%)\end{array}$ & $161.06 \pm 6.32^{b c}$ & $59.60 \pm 1.38^{a}$ & $199.45 \pm 1.79^{\mathrm{NS}}$ & $161.06 \pm 6.32^{b c}$ \\
\hline $\begin{array}{l}\text { Standard } \\
\text { drug (SD) }\end{array}$ & $\begin{array}{c}184.00 \pm \\
43.71 \\
(100 \%)\end{array}$ & $\begin{array}{c}173.33 \pm \\
51.05 \\
(95 \%)\end{array}$ & $\begin{array}{c}174.33 \pm \\
47.98 \\
(95 \%)\end{array}$ & $\begin{array}{c}186.00 \pm \\
48.28 \\
(101 \%)\end{array}$ & $179.41 \pm 6.51^{c}$ & $59.10 \pm 1.80^{a}$ & $199.45 \pm 1.79^{N S}$ & $179.41 \pm 6.51^{c}$ \\
\hline
\end{tabular}

Each value is the mean \pm S.D. for 4 rats. ${ }^{A}, b, c$ value with superscript letter means significant among the group at $p<0.05$. Ns Not significant.Group A $=50 \mathrm{mg} / \mathrm{kgbwt}$, Group B = $100 \mathrm{mg} / \mathrm{kgbwt}$, Group C = $200 \mathrm{mg} / \mathrm{kgbwt}$, Standard drug $(S D)=150 \mathrm{mg} / \mathrm{kgbwt}$.

Table 2. Effect of Centella asiatica on plasma triglyceride, total cholesterol, high density lipoprotein and low density lipoprotein concentration in alloxan-induced type 1 diabetic rats.

\begin{tabular}{lcccccc}
\hline Experimental Groups & TG $(\mathrm{mg} / \mathrm{dl})$ & TC $(\mathrm{mg} / \mathrm{dl})$ & HDL $(\mathrm{mg} / \mathrm{dl})$ & LDL $(\mathrm{mg} / \mathrm{dl})$ & SGOT $(\mathrm{mg} / \mathrm{dl})$ & SGPT $(\mathrm{mg} / \mathrm{dl})$ \\
\hline Normal & $53.80 \pm 5.29^{\mathrm{a}}$ & $59.92 \pm 4.89^{\mathrm{a}}$ & $59.47 \pm 2.97^{\mathrm{a}}$ & $16.27 \pm 3.35^{\mathrm{a}}$ & $68.07 \pm 12.01^{\mathrm{a}}$ & $24.62 \pm 8.99^{\mathrm{a}}$ \\
Diabetic control & $91.12 \pm 14.00^{\mathrm{b}}$ & $91.15 \pm 6.47^{\mathrm{b}}$ & $25.80 \pm 2.94^{\mathrm{b}}$ & $40.50 \pm 5.16^{\mathrm{b}}$ & $107.52 \pm 3.97 \mathrm{~b}$ & $62.55 \pm 0.62^{\mathrm{b}}$ \\
Diabetic+ Group A & $57.02 \pm 5.11^{\mathrm{ab}}$ & $64.65 \pm 3.72^{\mathrm{ab}}$ & $58.27 \pm 7.26^{\mathrm{b}}$ & $18.42 \pm 7.42^{\mathrm{b}}$ & $72.07 \pm 7.67^{\mathrm{b}}$ & $28.00 \pm 13.12^{\mathrm{b}}$ \\
Diabetic+ Group B & $68.47 \pm 4.74^{\mathrm{ab}}$ & $62.32 \pm 3.38^{\mathrm{b}}$ & $54.90 \pm 4.66^{\mathrm{b}}$ & $18.95 \pm 4.44^{\mathrm{b}}$ & $74.62 \pm 4.98^{\mathrm{b}}$ & $34.60 \pm 5.51^{\mathrm{ab}}$ \\
Diabetic+ Group C & $61.47 \pm 7.09^{\mathrm{b}}$ & $64.12 \pm 4.3^{\mathrm{NS}}$ & $57.37 \pm 8.27^{\mathrm{b}}$ & $18.62 \pm 3.41^{\mathrm{b}}$ & $82.72 \pm 6.13^{\mathrm{b}}$ & $26.15 \pm 3.68^{\mathrm{b}}$ \\
Standard drug (SD) & $57.33 \pm 6.0^{\mathrm{NS}}$ & $62.90 \pm 3.0^{\mathrm{NS}}$ & $58.40 \pm 7.46^{\mathrm{NS}}$ & $20.33 \pm 1.49^{\mathrm{NS}}$ & $83.23 \pm 4.74^{\mathrm{NS}}$ & $32.73 \pm 1.05^{\mathrm{NS}}$
\end{tabular}

Each value is the mean \pm S.D. for 4 rats. ${ }^{a}, b$ value with superscript letter in the same column significantly different among the group at $p<0.05 .^{N S}$ Not significant.Group $A=50 \mathrm{mg} / \mathrm{kgbwt}$, Group $B=100 \mathrm{mg} / \mathrm{kgbwt}$, Group $C=200 \mathrm{mg} / \mathrm{kgbwt}$, Standard drug $(\mathrm{SD})=150 \mathrm{mg} / \mathrm{kgbwt}$. TG $=$ Triglyceride, $\mathrm{TC}=$ Total cholesterol, $\mathrm{HDL}=$ High density lipoprotein, $\mathrm{LDL}=$ Low density lipoprotein. 
Effect of C. asiatica on plasma glucose level, lipid profile, SGPT, SGOT and organ weight: Significant reduction in plasma glucose level in the A. B, C and SD administered groups were observed with different extent (Fig.1). As much as $39.40 \%$ reduction in plasma glucose level was observed in group A where only $22.43 \%$ and $20.86 \%$ decrease in plasma glucose level could be noticed in group B and C, respectively. A significant reduction in TG, TC, HDL and LDL levels were noticed in all groups those administered $C$. asiatica and SD than to diabetic control (Table 2).

Table 3. Effect of Centella asiatica on various organ weight $(\mathrm{g})$ in alloxan induced diabetic type 1 rats

\begin{tabular}{lcccc}
\hline $\begin{array}{l}\text { Experimental } \\
\text { Groups }\end{array}$ & Heart wt & Liver wt & Kidney wt & Pancreas wt \\
\hline Normal & $0.51 \pm 3.10^{\mathrm{a}}$ & $5.09 \pm 0.41^{\mathrm{a}}$ & $1.37 \pm 0.15^{\mathrm{a}}$ & $0.34 \pm 2.50^{\mathrm{a}}$ \\
Diabetic control & $0.26 \pm 0.12^{\mathrm{b}}$ & $4.00 \pm 0.41^{\mathrm{b}}$ & $1.09 \pm 5.71^{\mathrm{b}}$ & $0.26 \pm 4.50^{\mathrm{b}}$ \\
Diabetic+ Gr A & $0.55 \pm 5.79^{\mathrm{b}}$ & $5.15 \pm 0.28^{\mathrm{b}}$ & $1.21 \pm 0.12^{\mathrm{b}}$ & $0.32 \pm 4.64^{\mathrm{b}}$ \\
Diabetic+ Gr B & $0.44 \pm 0.10^{\mathrm{NS}} 3.87 \pm 0.96^{\mathrm{NS}}$ & $1.15 \pm 0.13^{\mathrm{NS}}$ & $0.27 \pm 6.48^{\mathrm{NS}}$ \\
Diabetic+ Gr C & $0.52 \pm 0.15^{\mathrm{NS}} 3.99 \pm 1.11^{\mathrm{NS}}$ & $1.21 \pm 0.24^{\mathrm{a}}$ & $0.24 \pm 0.10^{\mathrm{NS}}$ \\
SD & $0.50 \pm 1.00^{\mathrm{NS}} 5.03 \pm 0.79^{\mathrm{NS}}$ & $1.22 \pm 0.11^{\mathrm{NS}}$ & $0.31 \pm 5.13^{\mathrm{NS}}$ \\
\hline Each value is the mean \pm S.D. for 4 rats. $^{\mathrm{a}} \mathrm{b}$, & value with superscript letter in
\end{tabular}

the same column significantly different among the group at $p<0.05$. NS Not

significant Group A $=50 \mathrm{mg} / \mathrm{kgbwt}$, Group B $=100 \mathrm{mg} / \mathrm{kgbwt}$, Group C $=200$

$\mathrm{mg} / \mathrm{kgbwt}$, Standard drug (SD) $=150 \mathrm{mg} / \mathrm{kgbwt}$.

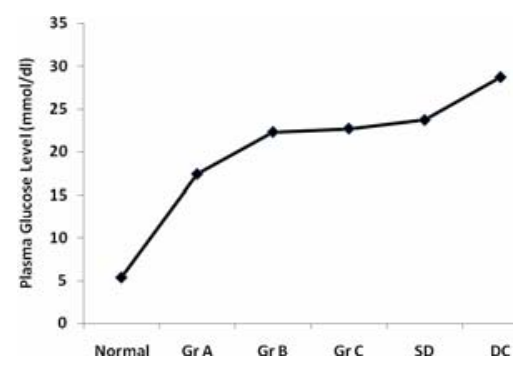

Fig. 1. Hypoglycemic effect of Centella asiatica in alloxaninduced type 1 rats by oral administration for 22 days. Each value is the mean \pm S.D. for 4 rats. ${ }^{a}, b, c$ value with superscript letter in the same column significantly different among the group at $p<0.05$. Group $A=50$ $\mathrm{mg} / \mathrm{kgbwt}$, Group B $=100 \mathrm{mg} / \mathrm{kgbwt}$, Group C $=200$ $\mathrm{mg} / \mathrm{kgbwt}$, Standard drug (SD) $=150 \mathrm{mg} / \mathrm{kgbwt}$

It was found that, group A performed better, which decreased the TG level as much as $37.42 \%$ as compared to diabetic control group $69.36 \%$. A substantial decrease in the plasma TC level $29.07 \%$ was found in group A, as compared to diabetic control group $52.11 \%$. Increased level of $\mathrm{HDL}$ as much as $125 \%$ as compared to diabetic control group $56.61 \%$ and decreased LDL level as much as $54.51 \%$ as compared to diabetic control group $148.92 \%$ were also found in group $A$.

The values of SGOT and SGPT were shown to be reduce in all $C$. asiatica and SD administered groups which was increased by injection of Alloxan for inducing diabetes (Table 2). Both SGOT and SGPT level were found to significantly lower in group A $32.97 \%$ and $55.23 \%$, respectively than the control group $57.19 \%$ and $154.06 \%$. Our results indicate significant reduction of both SGOT and SGPT value was evidenced under treatment of $C$. asiatica which signifies their corrective role in liver function of the diabetic rats.

In this investigation the heart, liver, kidney and pancreas weight were shown to be significantly improved in all C. asiatica and SD administered groups as compared to diabetic control group (Table 3).

\section{Discussion}

C. asiatica could repair the damage of the pancreatic $\beta$-cells and promote insulin synthesis, thus may lowering the level of plasma glucose. The two glycosides, brahmoside and brahminoside, which are principle constituents of $C$. asiatica have been shown to exert sedative and hypoglycemic effects in experimental rats (Ramaswamy et al., 1970). The triterpene in this plant had a significant effect on blood glucose, with initial glucose deviation of more than $30 \%$ and final deviation of more than $50 \%$, similarly to tolbutamide (Mutayabarwa et al. 2003). Chauhan et al. (2010) observed that both ethanolic and methanolic extracts has reduced the glucose levels to $51 \%$ and $69 \%$ respectively. According to Ramaswamy (1970) two glycosides, brahmoside and brahminoside, which are principle constituents of $C$. asiatica, have been shown to exert sedative and hypoglycemic effects in experimental rats and this is in support of the of the present finding which showed that the extract.was effective against alloxan induced diabetic rats. 
George et al. (2008) studied that the aqueous extract of $C$. asiatica exhibited anti-nociceptive activity in mice and anti-diabetic study indicated that the extract suppressed the elevated blood glucose, lipid levels didn't change in diabetic rats. Gayathri et al. (2011) induced diabetes in male Wister rats by streptozotocin $(50 \mathrm{mg} / \mathrm{kg})$ injection and the dose of $200 \mathrm{mg} / \mathrm{kg}$ of ethanol extract of $C$. asiatica showed significant antidiabetic activity as judged from body weight, serum glucose, lipids. cholesterol and liver glycogen levels.

Many works have observed elevation in transaminase activity (SGOT and SGPT) in liver and serum in diabetic rat (Ghosh and Suryawanshi 2001). The restoration of SGOT and SGPT to their respective normal level after treatment with $C$. asiatica strengthens the antidiabetogenic effect in this plant. Moreover, SGOT and SGPT level also act as indicators of liver function and restoration of normal level of this parameters indicate normal function of liver (Kumar and Loganathan 2010). The present results are complementary with the findings of other workers (Somani and Singhai 2008) as C. asiatica juice treated rats showed improvement in organ (heart, liver, kidney and pancreas) weight as compared to diabetic control rats.

\section{References}

Annapurna A, Kanaka, Mahalakshmi D, Krishna MK. 2001. Antidia- betic activity of a polyherbal preparation (tincture of punch- parna) in normal and diabetic rats. Indian J Exp Biol 39, 500-502. PMid:11510141

Bailey CJ, Day C. 1989. Traditional plant medicines as treatments for diabetes. Diabetes Care 12, 553-564. http://dx.doi.org/10.2337/diacare.12.8.553 PMid:2673695

Bhattacharya SK, Satyan KS, Chakrbarti A. 1997. Effect of Tra-sina, an Ayurvedic herbal formulation, on pancreatic islet superox-ide dismutase activity in hyperglycae-mic rats. Indian J Exp Bio/ 35, 297-299. PMid:9332177

Brinkhaus B, Lindner M, Schuppan D, Hahn EG. 2000. Chemical,pharmacological and clinical profile of the East Asian medical plant Centella asiatica. Phytomedicine 7(5), 427-448. http://dx.doi.org/10.1016/S0944-7113(00)80065-3

Chauhan PK, Pandey IP, Dhatwalia VK. 2010. Evaluation of the anti-diabetic effect of ethanolic and methanolic extracts of Centella asiatica leaves extract on alloxan induced diabetic rats. Adv Biol Res 4, 27-30.

Gayathri V, Lekshmi P, Padmanabhan RN. 2011. Anti-diabetes activity of ethanol extract of Centella asiatica (L.) Urban (whole plant) in streptoztocin-induced diabetic rats, isolation of an active fraction and toxicity evaluation of the extract. Int $J$ Med Arom Plants 1(3), 278-286.

George M, Joseph L, Ramaswamy AS. 2008. Effect of Centella asiatica extract on nociception, experimental diabetes and hyperlipidemia in mice and rats. Int J Biol Chem Sci 2 (1), 59-65

Ghosh S, Suryawanshi S.A. 2001. Effect of Vinca rosea extracts in treatment of alloxan diabetes in male albino rats. Indian J Expt Biol 39, 748-759. PMid:12018575

Ghosh R, Sharatchandra KH, Rita S, Thokchom IS. 2004. Hypoglycemic activity of Ficus hispida (bark) in normal and diabetic albino rats. Indian J Pharmacol 36, 222-225.

Haffner SM, Lehto S, Ronnemaa T, Pyorala K, Laakso M. 1998. Mortality from coronary heartdisease in subjects with type 2 diabetes and in nondiabetic subjects with and without prior myocardial infarction. $N$ Engl $J$ Med 339, 229-234. http://dx.doi.org/10.1056/NEJM199807233390404 PMid:9673301

James JT, Dubery IA. 2009. Pentacyclic triterpenoids from the medicinal herb, Centella asiatica (L.) Urban. Molecules 14(10), 39223941. http://dx.doi.org/10.3390/molecules14103922 PMid:19924039

Kumar JN, Loganathan P. 2010. Hypoglycemic effect of Spinacia oleracea in alloxan induced diabetic rat. Global J Biochem 5(2), 87-91.

Mitra SK, Gopumadhavan S, Muralidhar TS, Anturlikar SD, Sujatha MB. 1996. Effect of a herbomineral preparation D-400 in streptozotocin induced diabetic rats. J Ethnopharmacol, 54, 41-46. http://dx.doi.org/10.1016/0378-8741(96)01439-0

Mutayabarwa CK, Sayi JGM, Jande M. 2003. Hypoglycaemic Activity of Centella asiatica (L.) Urb. East Central Afr J Phar Sci 6, 30-35.

Ramaswamy AS. 1970. Pharmacological studies on Centella asiatica. J Res Indian Med 4, 160.

Ramaswamy AS, Perivasamy SM, Basu N. 1970. Pharmacological studies on Centella asiatica. J Res Indian Med 4, 160.

Somani RS, Singhai AK. 2008. Hypoglycaemic and antidiabetic activities of seeds of Myristica fragrans in normoglycaemic and alloxaninduced diabetic rats. Asian J Exp Sci 22(1), 95-102.

WHO (World Health Organisation).1980. The WHO Expert Committee on Diabetes Mellitus. Technical Report Series 646, Geneva, and WHO.

WHO (World Health Organisation).1985. Diabetes mellitus: Report of a WHO Study Group. 727. 